\title{
Think About the Legislative Purpose of Construction Project Priority —And Talk About the Sequence With the Mortgage
}

\author{
Yuan Ronghua \\ Luoshi Rode 122, Wuhan University of Technology, Wuhan, P.R.China,430070 \\ E-mail:1960862943@qq.com
}

\begin{abstract}
Although the Supreme People's Court's judicial interpretation stipulated the sequence between the construction project priority and the mortgage, but it is quite doubtful after reviewing the legislative purpose of construction project priority. Because the legislative intent of construction project priority is to protect the right of the contractor, not to solve the problem of wage arrears for labor as the mainstream view. From the basic principle of the property law, there is flaw in the system of construction project priority. Through the comparison analysis and research, finally proposed to establish construction project priority registration system in the civil code compiling, clear the registration time as the standard of sequence.
\end{abstract}

Keywords: Construction Project Priority; Legislative Purpose; Registration; Mortgage; Sequence

\section{Introduction}

To ensure the construction project cost of contractor can be realized, the article 286 of the contract law sets the construction project priority. And to solve its conflict with the mortgage, the Supreme People's Court judicial interpretation has made an arrangement that the construction project priority is prior to the mortgage. Academic circle basically agreed for the judicial interpretation, which also includes professor Liang Huixing. ${ }^{[1]}$ The reason of positive attitude mainly based on the interpretation of the legislative purpose of construction project priority. In summary: (1)Compared to the mortgagee such as back, in the relationship with the employer, the contractor located in disadvantage. Therefore, the contract law established the status of priority of the construction project cost, hoped to make up for the adverse situation of the contractor. (2)The construction project cost contains in the workers' wages which is related to the construction workers' right to exist. So, the contract law established the status of priority of the construction project cost, designed to protect construction workers living rights and interests, because the survival rights and interests of workers is greater than the interests of the mortgagee such as bank. By discussing the legislative intent of the construction project priority, this paper puts forward to legislative proposal to perfect the construction project priority, and to maintain the rights of the parties on the construction project.

\section{The Legislative Intent of Construction Project Priority: Safeguard the Rights and Interests of the Contractor}

At least until the contract law was enacted, laws and regulations which to regulate the construction market in China is incomplete. In the relationship of the employer and the contractor, the contractor located in disadvantage for the whole building industry present a situation of the developer market. The developer doesn't deliver the project funds to contractor in accordance with the terms of contract, even malicious defaults the project funds of contractor. The construction project funds which was in arrears explosive growth, it seriously affected the normal operation of the construction industry, endangered the social stability. According to the incomplete data, at the end of 1992, the project funds is in arrears of the national construction enterprises is 20 billion yuan, the figure in 1993 reached 308 billion yuan, more than 60 billion yuan in 1995. ${ }^{[2]}$ Based on the survey of construction times to the nationwide 80 large and medium sized construction enterprises in 1996, the project funds is in arrears already broken through 20 billion yuan in 1992 the national record. ${ }^{[3]}$ By the end of 1997, the incomplete statistics of China's Construction Industry Yearbook showed that the project funds is in arrears had more than 3566 billion yuan in 1997. 
In 1996, Shanghai happened a significant project settlement case. Shanghai alcohol factory went bankrupt because of the huge losses at a loss, in the process of bankruptcy liquidation, Shanghai construction as an ordinary creditors to participate in the liquidation procedures, only 190 thousand yuan was paid in 9.39 million yuan, and only $2.02 \%$ repayment rate. In July 1997, the National People's Congress specially to Shanghai listen to the opinion of "Building Law(draft)", tried to establish the system of the construction project priority in "Building Law". Later, the drafting team of "Building Law" and the drafting team of "Contract Law" closed a bargain, decided to establish the system in the contract law.

Therefore, the phenomenon of the developer illegal or malicious overdue payments the project funds was the legislative background of construction project priority. Contract law set the construction project priority is to protect the rights and interests of the contractor, and it is the legislative intent of the construction project priority. ${ }^{[4]}$

\section{Misreading of the Legislative Purpose of Construction Project Priority: Solve the Problem of Arrears of Wages}

Through the analysis of the legislative background of construction project priority, we can see that Contract law set the construction project priority is to protect the rights and interests of the contractor. However, the mainstream view think that the legislative purpose of construction project priority is to solve the problem of labor wages in arrears. Why is there this phenomenon? According to the views of the author, the problems is that most scholars think the project funds is not in place is the immediate cause of wages arrears. So, they associate the project funds with labor wages, and think construction project priority not only protect the creditor's rights of the contractor, but also solve the problem of labor wages. However, it is difficult to agree with this insight for author. The author don't deny that there is a connection between project funds and labor wages, and the realization of construction project priority may contribute to the solution of the problem of wage arrears for labor. But even the construction project priority guarantee to pay all the payment, there is no guarantee that the contractor will pay labor wages. From the reality, from the contract law to establish construction project priority in 1999, the problem of wage arrears for labor is still a major social problem.

\section{Defect of the System of Construction Project Priority: Damage the Interests of the Third Party}

Because of the misreading of the legislative purpose, the Supreme People's Court ruled that construction project priority should be realized before the mortgage when there is a conflict between them. However, this explanation has hit the legitimate rights and interests of the mortgagee such as bank. In the practice, the developer and contractor may be malicious collusion and against the mortgagee with fictional project funds. For example, the number 50 judgment was made by the Supreme People's Court in 2014. ${ }^{[5]}$ In the case, the Supreme People's Court did not support opinion of the Ping An bank Chongqing branch about the project funds is false litigation citing lack of evidence.

In such case, the mortgagee such as bank will assume the risk of losing. Because the mortgagee as the third person outside of the project construction contract, it is difficult to provide sufficient evidence for the fact that there is malicious between the employer and the contractor. Through the investigation, we can find that the reason is law gave the contractor construction project priority, but at the same time, the law did not ask it to take on the obligation of publicity. As a result, the mortgagee as the third person outside of the project construction contract, they don't know the real deal between the employer and the contract, and can't predict risk in advance.

In accordance with the principle, according to the theory of relativity of the creditor's rights, the debtor-creditor relationship between the employer and the contractor is "no use to tell others". But the contract law established the construction project priority, for its properties, although the academic circle have not reached a consensus, but there is no doubt that it is the legal real rights for 
security. ${ }^{[6]}$ The legal real rights for security as types of property right, it should follow the principle of the real right of the public under the condition of real right of priority preferential, so that it can safeguard the legitimate rights and interests of the third party outside of the employer and the contractor. It is a pity that the current legislation of construction project priority does not ask it to publicity, so it is against the principle of real right of the public.

\section{Legislative Proposal: the Perspective of Comparative Law}

\subsection{Extraterritorial Legislative Cases of Construction Project Priority}

In outside, there are legislation of construction project priority. Specifically: "The French Civil Code" regulates the real estate priority has the counter effectiveness after the registration, and regulates some constrains. "The Civil Code of Japan" regulates the real estate construction privilege has the priority within the scope of the registration. "The German Civil Code" regulates security mortgage of the contractor, it also needs to register. "The Swiss Civil Code" and "The Civil Code of Taiwan" stipulate the legal mortgage, and the registration time is the standard of sequence with the mortgage.

From outside the legislative cases of construction project priority, we can see that registration is the sign of producing the real right effect to construction project priority, and construction project priority may not necessarily priority even if it is dealt with registration.

\subsection{Establishing the Registration System of Construction Project Priority}

Through the above study, we can find that lack of the registration system of construction project priority will damage the principle of real right of the public, hurt the interests of the mortgage and general creditors. Therefore, by understanding of extraterritorial legislative cases of construction project priority, we should establish the registration system of construction project priority. Because it can protect the third party's right to now, prevent malicious collusion of the employer and contractors to damage the interests of the third party. ${ }^{[7]}$

The author find that although the nature of the construction project priority is the legal real right for security, but the legal real right for security is not necessarily superior to set the real right for security even in the extraterritorial legislative cases. And through the above review, we find that the legislative purpose of construction project priority is to protect the interests of the contractor. The establishment of the construction project priority has broken the principle of equality of creditor's rights, it gives the contractor the status of the priority than ordinary creditors, and the legislative purpose of protecting the interests of the contractor has been realized. The contractor and the mortgage (It is mainly bank) all belong to the operators, there is no interest order, and there is no need to break the priority principle of real right to protect the interests of the contractor, otherwise it will cause to the interests of the mortgagee. Because in the civil legal relationship, unless it is in the necessary circumstance, we should not deliberately create inequality between the equal civil subject. ${ }^{[8]}$

\section{Conclusions}

By reviewing the legislative purpose of construction project priority, inspecting the legislative defect of construction project priority, and analyzing extraterritorial legislative cases of construction project priority, in the civil code compiling, the author think that we should explicitly regulate the effect of real right of priority must through the registration in contract law legislation, otherwise it is can only be regarded as ordinary creditor's right, and determine the registration time as standard of sequence between construction project priority and mortgage. For ease of observation, look at the following table: 
Table 6.1 The Sequence of Construction Project Priority and Mortgage

\begin{tabular}{|l|l|l|}
\hline $\begin{array}{l}\text { Sequence } \\
\text { Project } \\
\text { Priority }\end{array}$ & Registration & Unregistered \\
\hline Registration & $\begin{array}{l}\text { Determination } \\
\text { According to the } \\
\text { Time of Registering }\end{array}$ & $\begin{array}{l}\text { Mortgage Ahead of } \\
\text { Construction } \\
\text { Project Priority }\end{array}$ \\
\hline
\end{tabular}

\section{References}

[1] Liang Huixing. "Interpretation" Conform to the Legislation Intention "Program" Should be Clear As Soon As Possible_- Interpretation of the Construction Project Priority. Information on http://www.abbs.com.cn/jzsb/read.php?recid=2894.

[2] Gu Changhao. Ma Beiyi. Sun Xiancheng. Construction Project Priority-Thinking the Legislative intention of Article 286 in the Contract Law. The Government Legal System Research. (2000).

[3] Zhao Xuming. Research the Conflict of Construction Project Priority and Mortgage. Civil Law and Commercial Law.( 2002).

[4] Liu Yongping. Several Problems of Construction Project Priority in the Practice. Journal of Law and Economy. (2016).

[5] Judgment of Second Instance of Ping An Bank Chongqing Branch Execution Objection Proceeding. http:/www.itslaw.com/detail?judgementId=153288d8-dbb5-4085-95e5-2375d01ed5ec\&area=1 \&inde $=1 \&$ sortType $=1 \&$ count $=173 \&$ conditions.

[6] Wang Xuguang. Research System of Construction Project Priority. The People's Court Press. Beijing. (2010).

[7] Hong Hao. Research the Problem of Construction Project Priority. Peking University Press. Beijing. (2014).

[8] Zhang Peng. Value Thinking of Construction Project Priority. Journal of Shanxi Politics and Law Institute for Administrators. (2011). 